\title{
Belgeo
}

Revue belge de géographie

3 | 2014

Art(s) \& Espace(s) / Art(s) \& Space(s)

\section{Young artists and the development of artistic quarters in Polish cities}

Jeunes artistes et développement des quartiers artistiques dans les villes polonaises

Jarosław Działek and Monika Murzyn-Kupisz

\section{OpenEdition}

\section{Journals}

Electronic version

URL: http://journals.openedition.org/belgeo/13012

DOI: $10.4000 /$ belgeo.13012

ISSN: 2294-9135

Publisher:

National Committee of Geography of Belgium, Société Royale Belge de Géographie

\section{Electronic reference}

Jarosław Działek and Monika Murzyn-Kupisz, « Young artists and the development of artistic quarters in Polish cities », Belgeo [Online], 3 | 2014, Online since 19 December 2014, connection on 02 May 2019. URL : http://journals.openedition.org/belgeo/13012 ; DOI : 10.4000/belgeo.13012

This text was automatically generated on 2 May 2019.

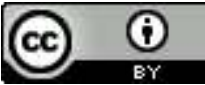

Belgeo est mis à disposition selon les termes de la licence Creative Commons Attribution 4.0 International. 


\title{
Young artists and the development of artistic quarters in Polish cities
}

\author{
Jeunes artistes et développement des quartiers artistiques dans les villes \\ polonaises
}

Jarosław Działek and Monika Murzyn-Kupisz

\section{AUTHOR'S NOTE}

The text was written as part of research carried out within the research project on "Activities of artists in post-socialist cities: socio-economic underpinnings and implications" conducted in 2013-2016 and financed with a grant awarded by the National Science Centre, Poland, grant agreement no. UMO-2012/05/E/HS4/01601. The authors would like to thank the two anonymous reviewers for their inspiring comments which helped to improve the text.

\section{Introduction}

1 At first glance, in many cities the activities of artists and other creatives seem to be concentrated in a few particular quarters, which thus become endowed with a distinctive atmosphere. A closer look at their spatial preferences, however, may reveal a more complex and less evident network of spatial behaviours that is not so easy to decipher (Brennan-Horley, 2010). The diverse and not necessarily overlapping aspects of their presence in urban space include their places of residence, their work, their social life, the spaces where they seek their artistic inspiration, and the venues of their artistic creation and presentation, and cultural and non-cultural consumption. These are not necessarily quarters where creatives both live and work (Zukin, Braslow, 2011). They are equally likely to be "lifestyle" creative quarters (Wedd et al., 2001), where artists seek inspiration, socialize, network, and establish professional contacts with art galleries or potential clients, show the products of their creative activities, and admire the cultural 
achievements of others (Currid, 2007; Heebels, van Aalst, 2010; Ambrosino, 2013), while they may actually do their own work or live in other parts of the city (Debroux, 2013b). Such spaces might be dispersed throughout the city, though in larger urban centres there is indeed a clear tendency among artists to cluster in selected quarters (Green, 1999; Ley, 2003, Lloyd, 2004; Currid, 2007; Brennan-Horley, Gibson, 2009). As a result such areas often start to be labelled creative quarters or districts (Wedd et al., 2001; Zukin, Braslow, 2011; Gornostaeva, Campbell, 2012), artists' or artistic quarters (Traversier, 2009; Ambrosino, 2013; Debroux, 2013b), or cultural production quarters (Smit, 2011). These spaces should be distinguished (Debroux, 2013b) both from "art quarters" oriented mainly toward cultural consumption and from "cultural quarters' planned and developed by public authorities, within which artistic production and consumption are an essential element of urban policies implemented with the aim of generating an image of a creative city, or urban regeneration strategies (Montgomery, 2003; McCarthy, 2006; Evans, 2009; Vivant, 2009; Murzyn-Kupisz, 2012; Zebracki, Smulders, 2012; Lavanga, 2013; Noonan, 2013). In this article we would like to focus on the first type of artist concentration and creative production mentioned above, i.e. quarters which to a large extent emerge and develop organically as a result of more or less spontaneous spatial choices and selforganisation processes by artistic communities within the urban space. At the same time, it is important to bear in mind that all the constitutive features of artistic quarters such as the concentration of artists and the visibility of their studios, concentration of infrastructure supporting artists and the presence of art in the public space (Lorente, 2008) can to some extent be influenced by public policy.

2 Artistic quarters are characterised by a significant temporal and spatial dynamic. They tend to emerge more or less spontaneously, develop and evolve to reach the peak of their popularity among artists, and then slowly lose importance as artistic interest migrates to other parts of the city. The larger a given urban centre is, the more potential there is to observe the evolution of artistic quarters and the life cycle of artistic areas in the context of the entire city, some emerging on its cultural map, others considered mature or even in decline (Cole, 1987; Green, 1999; Zukin, 2008; Zukin, Braslow 2011; Debroux, 2013a; Wedd et al., 2001).

3 The aims of this article are first to provide an overview of the scientific literature focusing on the role of artists in the processes of change in West European and American cities, with particular attention to existing studies and proposals regarding the various stages of development of artistic quarters and artists' perceptions of them. Secondly, the authors' intention is to test whether similar developments may be observed in postsocialist cities in Central and Eastern Europe, where market mechanisms were to a large extent "frozen" and urban processes distorted after 1945 (Hamilton et al., 2005; Sagan, Grabkowska, 2012; Sýkora, Bouzarovski, 2012). Although never entirely controlled by topdown decisions during Communist times, in the new political and economic context since the disappearance of the Iron Curtain, artist communities in Poland have been much more free to take decisions on where to live and create within a city. They soon began willingly to explore new urban spaces, though with time their spatial choices have been constrained by rising real estate prices and growing demand from stronger, commercial actors (Richards et al., 2010; Murzyn-Kupisz, 2012; Olszewska, 2012). The context in which they function is thus not only post-socialist but also increasingly neoliberal (Sagan, Szmytkowska, 2012), which is reflected in challenges connected with urban planning and market-driven, competition-oriented urban policies, among them the instrumentalisation 
of cultural and leisure policies as a means of urban development (e.g. the Cultural Capital of Europe bid in Katowice or the Winter Olympics bid in Krakow, rejected in a referendum by the residents of the city) (Tölle, 2013). This study therefore seeks to examine the spatial preferences expressed by artists in such a post-socialist and neoliberal urban laboratory.

\section{Stages of artistic quarters' development}

The first broadly discussed case of an emerging artists' quarter was the SoHo neighbourhood in New York, where in the 1970s artists spontaneously took over unused industrial buildings (Zukin, 1989). With time, as SoHo began to attract more mainstream artists, art galleries and non-artistic gentrifiers, some artists started to move to other post-industrial, working-class or ethnic neighbourhoods (Cole, 1987; Zukin, Braslow, 2011). This cycle of emergence, growing popularity, boom, and then decline of artistic concentration repeated itself in other New York districts, and has been observed in many other major North American and West European cities such as London (Green, 1999; Ambrosino, 2013; Gornostaeva, Campbell, 2012; Harris, 2011; While, 2003), Paris (Clerval, 2008; Collet, 2008; Vivant, 2009, 2010; Gravereau, 2013; Chabrol, 2011, Boichot, 2013), Berlin (Heebels, van Aalst, 2010; Boichot, 2013), Brussels (Debroux, 2013a, 2013b), Barcelona (Tremblay, Battaglia, 2012; Ballester, 2013), Montreal (Tremblay, Battaglia, 2012) and Toronto (Bain, 2003; Ley, 2003; Hracs, 2009; Matthews, 2008).

5 Such evolution of particular parts of metropolitan cities is not an entirely new phenomenon (Wedd et al., 2001; Traversier, 2009). In different periods of history, however, there have been different factors attracting artists to and pushing them out of particular urban areas depending on dominant social and cultural currents, the organization of the art market and the foremost art patrons. Although economic factors seem to be the most important influences on intra-urban migrations, aesthetic and symbolic considerations play a significant role, too. Artists and other cultural producers, particularly those at the early stages of their career, usually fall into low income groups, whose livelihood is precarious on many levels (Vivant, 2009, 2010; Comunian et al., 2010). Some of them may even be classifiable as the creative underclass (Gornostaeva, Campbell, 2012). Few talented young people are able to make a living from their creative endeavours. Even fewer will achieve any considerable success in the art market (Lloyd, 2004). For these reasons artists are often drawn to particular urban spaces by the availability of spacious, affordable spaces in dilapidated, lower-income neighbourhoods or post-industrial zones, where there is underused residential and commercial space in or near the city centre (Cole 1987; Green, 1999; Ley, 2003; Lloyd, 2004; Vivant, 2010; Zukin, Braslow, 2011; Lawton et al., 2012; Gravereau, 2013). One aspect of the preference for citycentre locations, in turn, is usually the need to sustain links with traditional cultural institutions situated in the urban core (often despite contesting them at the same time) (Gravereau, 2013; Debroux, 2013b).

6 The character of the local scenery and built environment, their "look and feel", are yet another factor drawing artists to historic neighbourhoods or post-industrial spaces rather than to new construction or the suburbs (Wedd et al. 2001; Bain, 2003; Heebels, van Aalst, 2010; Ryberg et al., 2013). The "authentic", "characterful" social settings of working-class or ethnic neighbourhoods are frequently preferred by artists to areas reflecting middle-class norms and values, which they tend to contest (Bain, 2003; Ley, 
2003; Cameron, Coaffee, 2005). Built form, like social and ethnic structure, creates an ambiance which may be a source of inspiration or a platform for artistic expression (Bain, 2003; Drake, 2003).

7 A newly discovered setting and its visual qualities may also be used to differentiate oneself from more "mainstream" parts of the city representing popular or high culture and well established art groups perceived as (too) conservative (Zukin, 2008; Harris, 2011; Smit, 2011). This is one way in which younger generations of artists may contest the artistic and spatial choices of their older colleagues. This contestation may be reflected in the search for new territories and alternative ways of expressing oneself and asserting a creative independence. Weaker social control over atypical behaviours is conducive to innovative artistic expression and development of non-standard aesthetic tastes which might be rather unwelcome in mature creative districts (Vivant, 2010; Slach et al., 2013). As Zukin and Braslow (2011, p. 136) claim, "a creative district locates, embodies, and represents a place where people can perform their difference from mainstream behavioural norms and social roles in relative safety, with few negative consequences to themselves or to the district as a whole." The new area may thus become the main foundation on which the symbolic socio-spatial identity and reputation of young artists is built (Bain, 2003; Drake, 2003; Lloyd, 2004; Zukin, 2008; Heebels, van Aalst, 2010; Ambrosino, 2013).

8 This symbolic aspect of breaking with the traditions of artistic predecessors in terms of both artistic expression and urban space was visible as early as in the second half of the $19^{\text {th }}$ century, when the first representatives of the bohemia, of which the French bohemians were the forerunners, turned their backs on the conservative art of the Academy, departing from creation of art for rich patrons towards art for art's sake (Wedd et al., 2001). Opting for life on the margins of society, they decided to or were forced to live together in liminal spaces of their cities, which they shared with other social groups who had no alternatives (Bain, 2003; Vivant 2010; Zukin, 2008). The search for authentic ethnic and working-class neighbourhoods is often romanticized, however, as relations between artists and these "authentic" social groups tend to be superficial due to the difference in cultural capital. Eventually, the newcomers try to subjugate these areas and fashion them into milieus that conform to their preconceived notions of authenticity (Cole, 1987; Zukin, 2008; Harris, 2011).

With time, the image of the alternative quarter brings a popularity that can ultimately also herald the decline of its function as an artistic niche. As formerly alternative artists start to cater to the tastes of higher-income groups who are exploring unknown, once "dangerous", marginal spaces, "bad" neighbourhoods gradually evolve into familiar, fashionable places (Gornostaeva, Campbell, 2012). Simultaneously, real estate developers waste no time promoting certain areas as "creative quarters" in order to make profits on selling upgraded premises to creative professionals and other non-creative tenants with greater financial resources. Both real estate developers and public officials apply the creative label to such quarters in order to translate the symbolic capital they represent into economic capital (Zukin, Braslow, 2011).

10 Artists and former inhabitants alike, despite frequent resistance and creative sabotage (Juskowiak, 2012), are gradually displaced ${ }^{1}$ by middle-class gentrifiers (Brooks, 2000; Ley, 2003; Catungal et al., 2009; Gravereau, 2013), who are attracted precisely by the artistic image of a quarter, as well as by the development of the evening and night economy in it. New, more wealthy residents become patrons of trendy, decreasingly alternative catering 
establishments, boutiques, galleries and other venues. As a result of growing demand from gentrifers and developers, real estate prices increase, becoming the main factor which forces artists to relocate to less expensive areas. Space dedicated to creative production gradually becomes space devoted to less and less creative consumption (Zukin, Braslow, 2011; Ambrosino, 2013). The reasons for the movement of artists are not only economic, however, but also aesthetic and symbolic. For some artists the decision to depart to new areas is a question of taste, and the perception that in a given area commercialised art is becoming more and more devoid of meaning. It is a way of showing discontent at the changes taking place in a quarter which is "no longer the same" as when the first artist pioneers "discovered" it, back in the time of an idealized "golden age" of the area (Ocejo, 2011).

The evolution of an artistic quarter towards gentrification does not only translate into changes in the socio-economic structure of its residents reflected in the inflow of representatives of different subgroups of the creative class (Ley 2003; Lloyd, 2004; Gornostaeva, Campbell, 2012). It also leads to changes in the functioning of the local economy, including artistic production, consumption and the functioning of artistic venues. At first artists occupy empty spaces, organize artists' squats, and transform them into underground cultural venues (Vivant, 2009, 2010). As creatives use urban space spontaneously and often in an ephemeral way, "fitting" their artistic ideas into existing urban tissue, at this point they may be called "space-run artists" (Swartz, 2010). At a later stage in the development of an artistic quarter some artists become "culturpreneurs" (Lange, 2011) and self-made gatekeepers as they open independent studios, or organize artist-run and cooperative galleries as an alternative to commercial non-artist managed venues (Sharon 1979; Green, 1999; Blessi et al., 2011; Ambrosino, 2013). They are able to showcase avant-garde and innovative though not so profitable artistic ideas, at the same time having the potential for more direct contact with their audiences and networking with peers (Sharon 1979; Zukin, 2008; Ambrosino, 2013).

12 Ultimately however, "off" culture, free of commercial, academic or fashion constraints, shifts "from decay to glamour" (Vivant, 2010, p. 138) and from "subcultures into semimainstream" (Gornostaeva, Campbell, 2012, p. 184). Street art is a good example of these processes. In the early phases of development of artistic quarters it is often anonymous, provocative, dissident and transgressive, which makes it rather repelling to middle-class residents or visitors. Later it gradually becomes aesthetically mainstream and often commercially oriented, its commodified versions expressing market norms (Mathews, 2008), subject to public control, which distinguishes between illegal, "bad" graffiti and good, aesthetically pleasing street art supported with public funds (McAuliffe, 2012). Some street art creators move from the milieu of underground, often illegal activities to become remunerated participants of street art festivals. Similarly, independent, grassroots art or music initiatives often evolve into large, publicly funded cultural events ("from festivals to festival markets", Ley, 2003, p. 2542) to attract tourists in the never-ending competition of eventification (Jakob, 2012). Areas undergoing gentrification are also characterized by a decreasing number of small to medium-sized venues hosting live music (Bennet, 2010). Commercial galleries open in the most popular quarters, following in the footsteps of artists (Molotch, Treskon, 2009; Ambrosino, 2013; Gravereau, 2013). The decline in the "artistic vitality" of an area is never total, however, but relative in terms of the mainstreaming of a place into an area of mass cultural consumption, the institutionalization and festivalisation of its arts scene, and its 
subjugation to neoliberal forces (e.g. the displacement of alternative art venues by nonartistic establishments due to high real estate prices or new real estate developments).

Changes in artistic quarters are likewise reflected in the way catering functions. At first artists are thrilled with the "authenticity" and "natural feel" of cheap, local bars and restaurants. Soon however, the cultural gap and the growing distance between newcomers and owners of long established venues and their former patrons prompts the newcomers to create new, "authentic" establishments in line with their ideas of the area. As described by Zukin (2008, p. 745): "while prices [in the pre-existing establishments] may be low, the product mix and décor are not aesthetically right". Alternative consumers start to gather in newly established independent cafes serving "cappuccino and brioche", eat organic or vegetarian food in "alternative" restaurants, drink "alternative" soda to de-cocacolonise their territory, buy food at "authentic" farmers' markets and from other independent retailers, and inspire the opening of other typically bohemian amenities (e.g. second-hand bookstores, vintage clothing stores, tattoo parlours) (Lloyd, 2004; Evans, 2009, Richards et al., 2010; Woldoff et al., 2011). All of the above are not only usually too expensive for less wealthy residents but create an urban environment which to a large extent alienates its former inhabitants. Further gentrification usually leads to the gradual takeover of the "alternative" establishments by larger chain stores, chain cafes and chic restaurants catering to the tastes of the rich clientele of creative professionals with less interest in alternative venues. Ley (2003, p. 2542) describes this as a process whereby cultural production is replaced by cultural economies, leading to "an intensified economic colonization of the cultural realm". Likewise, Zukin (2008, p. 732) summed up the changes observed in the New York district of SoHo in the following words: "First there were factories, then art galleries, and now chain stores". The typical evolution of artistic quarters described in literature is summarised in table 1 .

Table 1. Stages of development of artistic quarters.

\begin{tabular}{|l|l|l|l|l|l|}
\hline $\begin{array}{l}\text { Stages of } \\
\text { development }\end{array}$ & $\begin{array}{l}\text { Functions and } \\
\text { establishments }\end{array}$ & $\begin{array}{l}\text { Dominant } \\
\text { representatives } \\
\text { of the creative } \\
\text { class }\end{array}$ & $\begin{array}{l}\text { Gentrification } \\
\text { and real } \\
\text { estate prices }\end{array}$ & General image & $\begin{array}{l}\text { Possible } \\
\text { perception } \\
\text { by artists }\end{array}$ \\
\hline
\end{tabular}




\begin{tabular}{|c|c|c|c|c|c|}
\hline Early & $\begin{array}{l}\text { Alternative and } \\
\text { "off" art scenes } \\
\text { Traditional } \\
\text { dining places, } \\
\text { grocery shops } \\
\text { and other non- } \\
\text { artistic retail } \\
\text { establishments } \\
\text { and services }\end{array}$ & $\begin{array}{l}\text { Creative } \\
\text { underclass } \\
\text { Bohemians }\end{array}$ & $\begin{array}{l}\text { Pioneers } \\
\text { No or very } \\
\text { little } \\
\text { displacement } \\
\text { of former } \\
\text { residents } \\
\text { Tendency to } \\
\text { make use of } \\
\text { underused or } \\
\text { empty spaces } \\
\text { Affordable } \\
\text { prices in } \\
\text { comparison to } \\
\text { other parts of } \\
\text { the city }\end{array}$ & $\begin{array}{l}\text { Not widely } \\
\text { known } \\
\text { No particular } \\
\text { image or } \\
\text { notoriety } \\
\text { among the } \\
\text { general public }\end{array}$ & $\begin{array}{l}\text { New area for } \\
\text { artists } \\
\text { "Undiscovered } \\
\text { potential" } \\
\text { "Niche, avant- } \\
\text { garde" }\end{array}$ \\
\hline Intermediate & $\begin{array}{l}\text { Alternative and } \\
\text { "off" art scenes } \\
\text { evolving into } \\
\text { semi- } \\
\text { mainstream } \\
\text { Establishment } \\
\text { of regular/more } \\
\text { permanent } \\
\text { artist-run art } \\
\text { spaces, and } \\
\text { galleries of } \\
\text { other art venues } \\
\text { Beginnings of } \\
\text { upgrading and } \\
\text { functional } \\
\text { changes in } \\
\text { terms of retail } \\
\text { and services }\end{array}$ & $\begin{array}{l}\text { Bohemians } \\
\text { Creative } \\
\text { entrepreneurs }\end{array}$ & $\begin{array}{l}\text { Artistic } \\
\text { followers of } \\
\text { pioneers } \\
\text { First classic } \\
\text { gentrifiers } \\
\text { Beginning of } \\
\text { displacement } \\
\text { of former } \\
\text { residents and } \\
\text { rising real } \\
\text { estate prices }\end{array}$ & $\begin{array}{l}\text { Artistic image } \\
\text { starts to } \\
\text { coexist with } \\
\text { former } \\
\text { negative } \\
\text { connotations }\end{array}$ & $\begin{array}{l}\text { Becoming } \\
\text { trendy } \\
\text { among } \\
\text { artists } \\
\text { "Inspiring" } \\
\text { "Perfect to } \\
\text { present my } \\
\text { art" }\end{array}$ \\
\hline
\end{tabular}




\begin{tabular}{|c|c|c|c|c|c|}
\hline Mature & $\begin{array}{l}\text { Mainstream art } \\
\text { scenes, non- } \\
\text { artist managed } \\
\text { spaces, art } \\
\text { galleries and } \\
\text { other cultural } \\
\text { venues } \\
\text { Increasingly } \\
\text { trendy and } \\
\text { commercialized } \\
\text { retail and } \\
\text { service venues }\end{array}$ & $\begin{array}{l}\text { Established } \\
\text { artists } \\
\text { Creative } \\
\text { entrepreneurs }\end{array}$ & 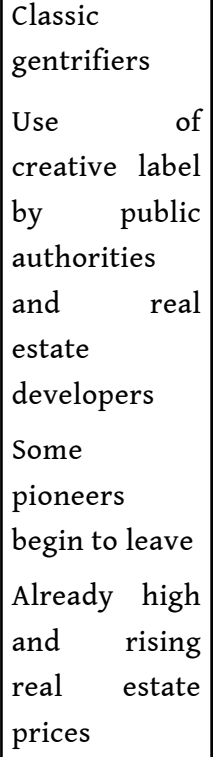 & $\begin{array}{l}\text { Universally } \\
\text { acknowledged } \\
\text { artistic image } \\
\text { Fashionable } \\
\text { and well } \\
\text { known among } \\
\text { non- } \\
\text { bohemians }\end{array}$ & $\begin{array}{l}\text { Established } \\
\text { and } \\
\text { "confirmed" } \\
\text { artistic } \\
\text { quarter } \\
\text { "Vibrant, } \\
\text { artistic" } \\
\text { "Good for } \\
\text { networking" }\end{array}$ \\
\hline Declining & $\begin{array}{l}\text { Evening and } \\
\text { night-time } \\
\text { economy } \\
\text { Trendy and } \\
\text { commercialized } \\
\text { retail and } \\
\text { service venues, } \\
\text { chain stores, } \\
\text { boutiques, and } \\
\text { cafes }\end{array}$ & $\begin{array}{l}\text { Creative } \\
\text { professionals }\end{array}$ & $\begin{array}{l}\text { Domination of } \\
\text { non-artistic } \\
\text { gentrifiers } \\
\text { and financial } \\
\text { gentrification } \\
\text { Userrof of } \\
\text { creative label } \\
\text { by public } \\
\text { authorities } \\
\text { and real } \\
\text { estate } \\
\text { developers } \\
\text { Very high real } \\
\text { estate prices }\end{array}$ & $\begin{array}{l}\text { Good image as } \\
\text { an established } \\
\text { "cool" and } \\
\text { trendy place, } \\
\text { well known to } \\
\text { non- } \\
\text { bohemians }\end{array}$ & $\begin{array}{l}\text { Ambiguous } \\
\text { or negative } \\
\text { among } \\
\text { bohemians } \\
\text { "Trendy to go } \\
\text { out" } \\
\text { "Used to be } \\
\text { popular" }\end{array}$ \\
\hline
\end{tabular}

Source: own elaboration based on literature referenced in the text

14 Finally, it is worth underlining that the stages of the development of an artistic quarter described above do not necessarily happen everywhere in a similar, linear order. On the contrary, as stated by Ley (2003: 2541), such transformations occur "in a typical but by no means inevitable sequence". More or less random stimuli, such as economic crisis, may also reverse the processes of change. The various stages are thus ideal types, whereas a unique set of features specific to the artistic life of a given area may dominate or be particularly visible there. The pace of the changes, their features, and the duration of particular stages may also vary from place to place, depending on the local social, cultural and economic context, especially taking into account that the existing publications pertain mainly to cities in highly developed countries of Western Europe and North America. 


\section{The case of young artists in Krakow and Katowice}

In order to broaden the perspective on artistic quarters to include evidence from Central and Eastern Europe, in the text the functions and understanding of artistic spaces are analysed using spatial perceptions of young artists studying art majors in two Polish cities: Krakow and Katowice. It seemed worthwhile to explore their opinions and preferences, since within the next few years, if they remain in the cities in question (Działek, Murzyn-Kupisz, 2014), these young creatives will be shaping the dynamics of the artscape in both cities.

Two large urban centres in southern Poland, Krakow and Katowice, are used by the authors to illustrate some patterns and tendencies in the spatial choices of young artists in Poland. Although both cities share the experiences of the Communist times and the post-socialist transformation, their development paths differ significantly (Katowice, see e.g. Murzyn-Kupisz, Gwosdz, 2011; Gwosdz 2014; Krakow, see e.g. Purchla, 2000) and are reflected in their built tissue, urban structure, contemporary functions and image (tab. 2.).

Table 2. Specific features of Krakow and Katowice.

\begin{tabular}{|c|c|c|}
\hline & Krakow & Katowice \\
\hline Population & $758,300(2012)$ & $307,200(2012)$ \\
\hline History & $\begin{array}{l}\text { - a major urban centre in Central } \\
\text { Europe since the Middle Ages } \\
\text { - well preserved medieval city centre } \\
\text { - considered a city of monuments and a } \\
\text { city of the "heritage industry" since the } \\
19^{\text {th }} \text { century }\end{array}$ & $\begin{array}{l}\text { - early } 19^{\text {th }} \text {-century origins } \\
\text { - rapid growth as the major urban } \\
\text { centre of the Upper Silesian } \\
\text { metropolitan area (pop. } 1.9 \text { million in } \\
2012 \text { ) } \\
\text { - continuous prosperity in the } 19^{\text {th }} \\
\text { century, interwar and post-WWII period } \\
\text { as the heart of a region of heavy } \\
\text { industry }\end{array}$ \\
\hline $\begin{array}{l}\text { Urban } \\
\text { functions }\end{array}$ & $\begin{array}{l}\text { - lack of major industrial traditions } \\
\text { until the 1950s (establishment of a steel } \\
\text { mill and planned city of Nowa Huta) } \\
\text { - considered a city focused on culture } \\
\text { and science, although some post- } \\
\text { industrial areas do exist }\end{array}$ & $\begin{array}{l}\text { - historically a service centre by a } \\
\text { railway station serving other industrial } \\
\text { towns in the region } \\
\text { - surrounded by mono-functional } \\
\text { industrial settlements (many } \\
\text { incorporated into the city after WWI } \\
\text { and WWII) }\end{array}$ \\
\hline $\begin{array}{l}\text { Urban } \\
\text { structure }\end{array}$ & $\begin{array}{l}\text { - dominant city in the region } \\
\text { - clear city centre, concentric } \\
\text { development until WWII } \\
\text { - changing context and patterns of } \\
\text { development after WWII }\end{array}$ & $\begin{array}{l}\text { - polycentric structure of the } \\
\text { conurbation } \\
\text { - dispersed structure of the city } \\
\text { - lack of a clear city centre }\end{array}$ \\
\hline
\end{tabular}




\begin{tabular}{|c|c|c|}
\hline Image & $\begin{array}{l}\text { - cultural capital of Poland } \\
\text { - major Polish historic city and a } \\
\text { UNESCO World Heritage site } \\
\text { - university city }\end{array}$ & $\begin{array}{l}\text { - no clear image or partly negative } \\
\text { image of an industrial city } \\
\text { - efforts to change this perception in } \\
\text { recent years }\end{array}$ \\
\hline $\begin{array}{l}\text { Young } \\
\text { artists }\end{array}$ & $\begin{array}{l}5,421 \text { students (in 2011) of artistic } \\
\text { majors studying at } 7 \text { HEIs }\end{array}$ & $\begin{array}{l}2,554 \text { students (in 2011) of artistic } \\
\text { majors studying at } 4 \text { HEIs }\end{array}$ \\
\hline
\end{tabular}

Source: own elaboration

17 At the same time they are interesting to examine as good examples of two major types of larger cities in the Polish urban system ${ }^{2}$. Krakow represents the first type: the group of cities with a long history dating back to the Middle Ages, acknowledged as multifunctional urban centres with rich and diverse heritage, such as Wroclaw, Poznan or Gdansk. Katowice, on the other hand, may to some extent share similar experiences with other younger, industrial cities such as Lodz, as an important regional capital with a much shorter history, which developed dynamically as an important industrial centre in the $19^{\text {th }}$ century and has seen significant restructuring processes and development challenges in recent decades. Moreover, although there is no clear and comprehensive creative city or cultural district development policy in either of the two cities, in both of them the public authorities have in recent years undertaken investments and projects which could significantly influence the development of artistic quarters. In Krakow such recent implicit cultural policies have included flagship investments in museums and major festivals, as well as smaller programmes such as renting municipal premises to artists and art galleries at preferential rates. In Katowice it is visible in the significant involvement of local authorities in the European Cultural Capital 2016 bid, which presented Katowice as a cultural "city of gardens", two major flagship investments in the post-industrial area north of the city centre (a new concert hall for the Polish National Radio Symphony Orchestra and a new seat for the Silesian Museum), as well as smaller cultural initiatives such as "Room for Culture" as a means of stimulating regeneration in the city centre.

\section{Research design}

This analysis of perceptions of changing artistic spaces in both cities is based on the opinions of students studying at academies of fine arts, music conservatories, higher schools of the dramatic arts, or majoring in TV and film production, architecture, design, or related subjects at other institutions of higher education. A questionnaire survey was addressed to students of artistic majors at all public and private HEIs offering such courses in both cities. ${ }^{3}$ Respondents were asked, among other things, to identify places, streets, zones or quarters to which different meanings could be attached and which could be understood as reflecting different stages of development as artistic quarters (see: last column of tab. 1). Specific, detailed questions asked about the perception of areas which:

1. were seen as being at an early stage of development as an artistic quarter, i.e.:

- have still not been discovered, though possess considerable artistic potential, and may see interesting developments in the future; 
- are considered niche, avant-garde places still not taken over by mass culture, where unique, alternative developments are currently taking place;

2. were seen as being at an intermediate stage of development as an artistic quarter, i.e.:

- have spaces and sites which could be considered inspiring from the point of view of students' creative endeavours;

- have places and spaces ideal (from a student's point of view) for organizing an artistic event (regardless of the real wherewithal to do so at the present);

3. were seen as mature artistic quarters, i.e.:

- are places which are currently among the most significant on the artistic map of the city: vibrant, dynamic, "full" of artists and artistic activities;

- have venues important and worth visiting (at least from time to time) in order to meet people important for a given artistic genre, and/or network with other artists and potential employers or patrons;

4. were seen as being at a late or declining stage of development as an artistic quarter, i.e.:

- are trendy or popular with the student and his/her peers as a place to go out, known for their night-time economy;

- used to be popular but no longer attract as much interest and are not as often visited or "used" by artists as in the past.

19 Answers were provided by 275 out of the 328 survey participants in Krakow and 95 out of the 116 in Katowice (in total about $6 \%$ of the art student population in each city). The number of questionnaires roughly reflected the proportions of students studying in each city in question (see tab. 2). Responses included references to particular places and venues in the urban space which could be located on the map of a given city, as well as more general statements to which particular locations could not be assigned (i.e. cinemas, cafés in general). Only the former, which could be "translated" onto a map, were included in the analysis. They were mapped using GIS tools as points, lines or polygons which could be ascribed to a particular territorial unit in a given city ${ }^{4}$ (tab. 3, tab. 4). As a result, a map was created reflecting young artists' perceptions that could be referred to the dynamics of artistic quarters at different stages of their development (fig. 1).

Table 3. Most important distinct areas and quarters in Krakow and Katowice mentioned in the text (for locations see fig. 1).

\begin{tabular}{|l|l|l|}
\hline \multicolumn{2}{|l|}{ Quarters and areas } & $\begin{array}{l}\text { Short } \\
\text { description/ } \\
\text { main features }\end{array}$ \\
\hline in Krakow & $\begin{array}{l}\text { Medieval town core and town centre perceived as such until today, with most } \\
\text { important, famous historic landmarks and established cultural institutions, a } \\
\text { UNESCO World Heritage site. }\end{array}$ \\
\hline Kazimierz & $\begin{array}{l}\text { Former medieval town with important Christian and Jewish religious sites, a } \\
\text { world-famous Jewish quarter and a 19 } \\
\text { UnES century municipal infrastructure zone, a } \\
\text { after 1945. Famous in Poland for its transformation into a cultural, tourism and } \\
\text { night-life area after 1989. }\end{array}$ \\
\hline
\end{tabular}




\begin{tabular}{|c|c|}
\hline $\begin{array}{l}\text { Old } \\
\text { Podgórze }\end{array}$ & $\begin{array}{l}\text { Historic former town established by the Hapsburgs at the end of the } 18^{\text {th }} \text { century. } \\
\text { Traditionally seen as less prestigious and more working-class and industrial than } \\
\text { Krakow proper. Relatively poor image after } 1945 \text {. Removal of industrial functions } \\
\text { after } 1989 \text {. }\end{array}$ \\
\hline Zabłocie & $\begin{array}{l}\text { A historic industrial zone of Podgórze developed in the } 19^{\text {th }} \text { and early } 20^{\text {th }} \\
\text { centuries. } \\
\text { A post-industrial area unique in the context of Krakow, which experienced rapid } \\
\text { deindustrialization after } 1989 \text {. }\end{array}$ \\
\hline Nowa Huta & $\begin{array}{l}\text { A district established after World War II as the "ideal Communist town" and the } \\
\text { living quarters for the biggest steelworks in post-war Poland. A symbol of } \\
\text { Communist successes after 1945, seen as unique (e.g. Socialist Realist } \\
\text { architecture) but with problematic heritage, and experiencing social and } \\
\text { economic problems after } 1989 \text {. }\end{array}$ \\
\hline \multicolumn{2}{|l|}{ in Katowice } \\
\hline $\begin{array}{l}\text { Inner City } \\
\text { Centre }\end{array}$ & $\begin{array}{l}\text { The part of the inner city north of the main railway line. Developed intensively } \\
\text { as a service and residential area especially in the } 19^{\text {th }} \text { and early } 20^{\text {th }} \text { centuries } \\
\text { under Prussian/German rule, and also to some extent in Communist times. } \\
\text { Important commercial and cultural functions until today. }\end{array}$ \\
\hline $\begin{array}{l}\text { Inner City } \\
\text { South }\end{array}$ & $\begin{array}{l}\text { The part of the inner city south of the main railway line, developed particularly } \\
\text { intensively by the Polish authorities in interwar times. Important educational, } \\
\text { religious and administrative functions until today. }\end{array}$ \\
\hline $\begin{array}{l}\text { Inner City } \\
\text { North }\end{array}$ & $\begin{array}{l}\text { An area north of the } 19^{\text {th }} \text { and early } 20^{\text {th }} \text {-century centre. Developed and } \\
\text { reconstructed mainly during Communist times, with major post-war } \\
\text { architectural landmarks and the best known cultural venue in Katowice } \\
\text { (Spodek). Includes a major post-industrial area: the site of the former Katowice } \\
\text { Coal Mine. }\end{array}$ \\
\hline Nikiszowiec & $\begin{array}{l}\text { Early } 20^{\text {th }} \text {-century working-class settlement next to a coal mine. Perceived as an } \\
\text { exceptionally well preserved and architecturally valuable example of an } \\
\text { industrial settlement. Major social and economic problems connected with } \\
\text { industrial restructuring after } 1989 \text {. }\end{array}$ \\
\hline Ligota & $\begin{array}{l}\text { A former village existing since medieval times. Development of heavy industry } \\
\text { (coal mining, steelworks) in the } 19^{\text {th }} \text { century. Intensive development in the } 19^{\text {th }} \\
\text { and early } 20^{\text {th }} \text { century under German and Polish rule, to some extent continued } \\
\text { in Communist times (socialist housing estates). }\end{array}$ \\
\hline
\end{tabular}


Table 4. Location of areas of artistic and night life indicated by students of art majors.

\begin{tabular}{|c|c|c|c|c|c|c|}
\hline \multicolumn{7}{|c|}{ KRAKÓW } \\
\hline \multirow{3}{*}{$\begin{array}{c}\text { Stages of artistic } \\
\text { quarter } \\
\text { development }\end{array}$} & Administrative district & \multicolumn{2}{|c|}{ I. Old Town } & \multicolumn{2}{|c|}{ XIII. Podgórze } & \multirow{2}{*}{$\begin{array}{c}\text { XVIII. } \\
\text { Nowa Huta } \\
\text { XVIII.1-12 } \\
\text { Nowa Huta }\end{array}$} \\
\hline & Urban unit & I.1 Old Town & I.7 Kazimierz & $\begin{array}{l}\text { XIII.3 Old } \\
\text { Podgórze }\end{array}$ & $\begin{array}{c}\text { XIII.4 } \\
\text { Zabłocie }\end{array}$ & \\
\hline & Places... & \multicolumn{5}{|c|}{ Share of answers as a \% } \\
\hline \multirow{2}{*}{ early } & with undiscovered potential & & 10.9 & 20.2 & 7.0 & 17.1 \\
\hline & niche, avant-garde & 13.5 & 29.0 & 15.5 & 11.0 & 9.7 \\
\hline \multirow{2}{*}{ intermediate } & inspiring & 26.3 & 20.4 & 11.7 & 7.3 & 4.7 \\
\hline & perfect to present my art & 38.0 & 9.2 & 6.4 & 12.0 & \\
\hline \multirow{2}{*}{ mature } & vibrant artistic & 41.4 & 38.4 & 4.7 & 4.4 & \\
\hline & good for artistic networking & 44.8 & 16.5 & 5.2 & 9.5 & \\
\hline \multirow{2}{*}{ declining } & trendy for going out & 53.4 & 27.1 & & & \\
\hline & used to be popular & 55.7 & 18.8 & 4.3 & & \\
\hline \multicolumn{7}{|c|}{ KATOWICE } \\
\hline \multirow{3}{*}{$\begin{array}{c}\text { Stages of artistic } \\
\text { quarter } \\
\text { development }\end{array}$} & Urban unit & \multicolumn{3}{|c|}{ A. Inner City } & $\begin{array}{l}\text { U. Janów } \\
\text { - Niki- } \\
\text { szowiec }\end{array}$ & $\begin{array}{l}\text { L. Ligota - } \\
\text { Panewniki }\end{array}$ \\
\hline & Urban sub-unit & $\begin{array}{c}\text { A1 (Inner } \\
\text { City - } \\
\text { Centre) } \\
\end{array}$ & $\begin{array}{c}\text { A2 (Inner City } \\
\text { - South) }\end{array}$ & $\begin{array}{l}\text { A3 (Inner } \\
\text { City - } \\
\text { North) } \\
\end{array}$ & $\begin{array}{l}\text { U1 (Niki- } \\
\text { szowiec) }\end{array}$ & Ł2 (Ligota) \\
\hline & Places... & \multicolumn{5}{|c|}{ Share of answers in \% } \\
\hline \multirow{2}{*}{ early } & with undiscovered potential & 18.5 & 18.5 & 11.1 & 14.8 & 11.1 \\
\hline & niche, avant-garde & 32.5 & 20.0 & 6.3 & 17.5 & 10.0 \\
\hline \multirow{2}{*}{ intermediate } & inspiring & 24.6 & 47.7 & & 9.2 & \\
\hline & perfect to present my art & 37.5 & 33.8 & 18.8 & & \\
\hline \multirow{2}{*}{ mature } & vibrant artistic & 41.2 & 50.9 & 7.4 & & \\
\hline & good for artistic networking & 32.8 & 62.7 & 6.7 & & \\
\hline \multirow{2}{*}{ declining } & trendy for going out & 67.2 & 24.6 & & & \\
\hline & used to be popular & 51.4 & 29.2 & & & 5.6 \\
\hline
\end{tabular}

NOTE: THE TABLE SHOWS THE SHARE OF SITES, STREETS, AREAS, VENUES ETC. INDICATED BY STUDENTS AND LOCATED WITHIN PARTICULAR QUARTERS - ONLY QUARTERS WHERE OVER 4\% OF ALL THE PLACES LISTED IN A gIVEN CATEgORY ARE LOCATED ARE SHOWN.

Source: own elaboration

\section{Discussion of findings}

\section{Krakow}

Among the areas and spaces in Krakow perceived by aspirational bohemians as the most artistically vibrant, two quarters dominate: the old Town and Kazimierz (fig. 1-2c, tab. 4). Kazimierz in particular, the historic Jewish-Christian town, visibly functions as an artistic quarter in the minds of creative students. They automatically mention its name, referring to it as a broader area and not to any individual venues, institutions or streets. The same is true of the Old Town, although in this case a dozen or so specific places were named. Apart from these two epicentres of artistic life two other quarters, Old Podgórze and Zabłocie, were mentioned, though markedly less often, both on the opposite bank of the Vistula river in the historic town of Podgórze. In the case of Zabłocie the main reason for its mention was the Museum of Contemporary Art in Krakow (MOCAK) - a flagship cultural project of the Krakow authorities adjacent to the "Schindler's Factory" Museum, both opened in 2010 (Murzyn-Kupisz, 2012). Among the institutions, buildings or sites mentioned explicitly by name, the largest number of respondents listed the Academy of Fine Arts, located on the northern edge of the old Town (nearly 4\%). 
Figure 1. Perceptions of students of artistic majors with respect to different artistic spaces in Krakow and Katowice.

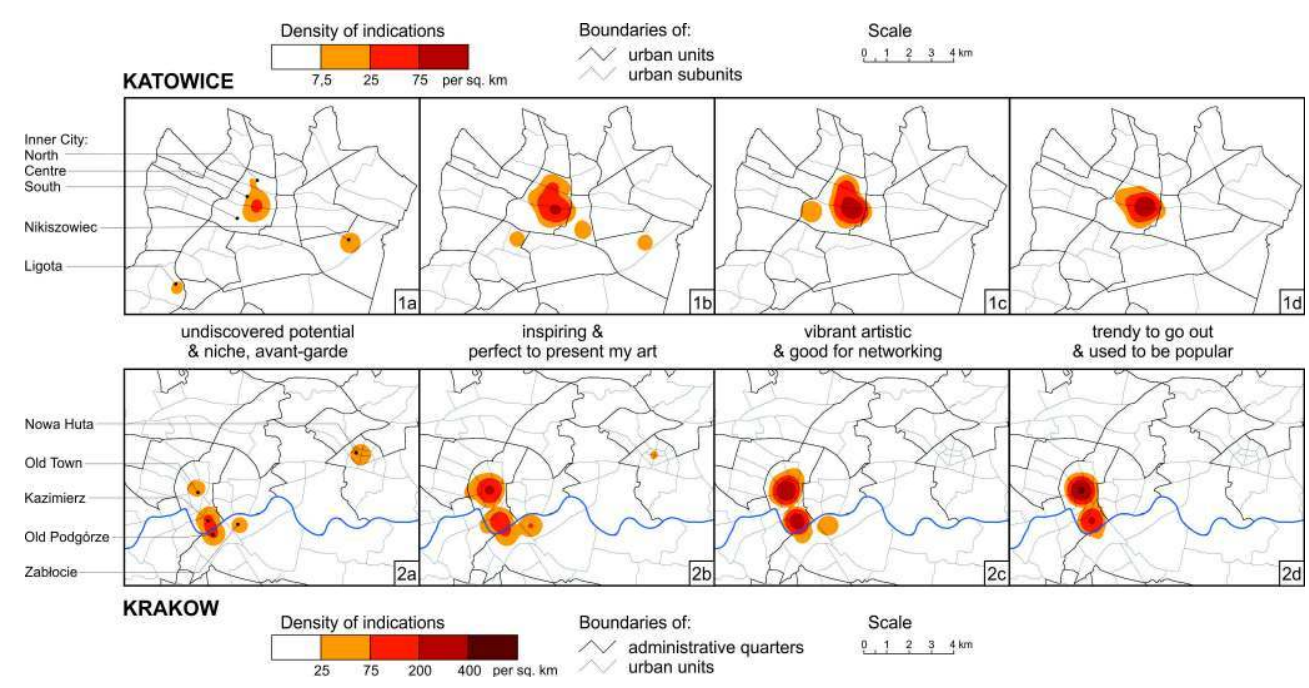

SOURCE: OWN ELABORATION

The youngest generation of artists in Krakow gave a large number of places (cultural institutions, artistic schools, clubs, cafes) where they can network and have access to cultural gatekeepers. Most of them are located in the Old Town (such as the Association of Polish Architects, the public modern art gallery Bunkier Sztuki ['Bunker of Art'] and its cafe, the Academy of Music, the Piwnica Pod Baranami ['The Cellar under the Rams'] literary cabaret, the Stary ['Old'] Theatre, a prestigious national theatre in Krakow, and Harris Piano Jazz Bar or on its fringes (the Academy of Fine Arts, the Philharmonic Hall, the Krakow Opera, and Małopolska Garden of Art - a new, multifunctional cultural space developed by the regional authorities). Most of these are established public institutions but the list also includes newer, flagship cultural investments on the edge of the old Town completed in the last decade or so. One in six respondents also points to Kazimierz as a quarter where it is worth spending time to establish contacts important for young artists. Two other areas are visible on the artistic networking map: Zabłocie (with MOCAK) and Old Podgórze (with the private KSA Krakow School of Art and Design).

Structures of longue durée such as traditional cultural institutions of high culture strengthen and sustain the position of the Old Town as an artistic quarter where young artists seek out possibilities to enter the professional world. A gradual spreading of artistic spaces to the edges of the old Town and two areas on the other bank of Vistula is visible, however. Kazimierz stands in opposition to the highly institutionalized, mainstream artistic life of the Old Town. After 1989 no major cultural investment was implemented in the area, to some extent due to a rather laissez-faire attitude of the public authorities, who were satisfied with the spontaneous regeneration of the district, and to a lack of larger empty spaces or post-industrial sites where such investments could be located (the long-term project of the conversion of the former tram depot complex into the Museum of Municipal Engineering is an exception). On the other hand, Kazimierz has spontaneously become a space of many independent initiatives: small theatres, galleries and numerous cafes combining catering with art shows, film screenings and live music venues (Murzyn, 2006; Murzyn-Kupisz, 2012). 
23 Kazimierz is also most often mentioned as the current main night-life and entertainment area of the city (fig. 1-2d), where artistic spaces rub shoulders with numerous cafes and clubs. Still, if one takes into account all the spaces, streets, squares and other sites mentioned explicitly by students, the old Town remains the area with the highest concentration of night economy outlets popular among young artists. In the city core, aside from cafes, pubs and dance bars, an important role is played by venues run by culturpreneurs which combine independent artistic endeavours with entertainment, giving them the possibility to both make a living and finance cultural activities. These include Bunkier Sztuki cafe, Bomba, with its alternative music scene, Pauza with photographic exhibitions, and until recently an independent cinema and an art gallery; and in Kazimierz Alchemia with its own small performance space offering independent music concerts and film screenings. In other areas of the city one venue that should be mentioned is Forum Przestrzenie (Forum Space), noticed by students despite only having been in existence for a few months before the survey was conducted. It is a club and event space opened in early 2013 in a socialist-era former hotel building earmarked for demolition, on the riverbank across from Kazimierz. The new venue houses units including a shop with fashion designed by young designers. The tea parlour Nie lubiF poniedziałków ("I don't like Mondays"), which organises literature and artistic meetings and is located north of the city core, is another place mentioned by aspirational bohemians.

24 When asked to name spaces and areas which are no longer popular, some students mentioned the Old Town and Kazimierz again, the former more frequently. The growing commercialization and touristification of the old Town is having an increasingly negative impact on its artistic reputation, which repels some artists from it. Similar processes are also to some extent being observed in Kazimierz, which is reflected not only in creative students' opinions but also in the discourse on changes taking place in the quarter (Murzyn-Kupisz, 2012). Kazimierz will not lose its status as an area with artistic vitality so easily or quickly, however. This is confirmed by the fact that every third respondent mentioned this former historic town, or venues and sites in it, as spaces of niche or avantgarde artistic endeavours (fig. 1-2a). Moreover, many aspiring artists continue to search for inspiration in this quarter. 
Figure 2. Art students' perceptions of the dynamics of artistic quarters in Krakow and Katowice.
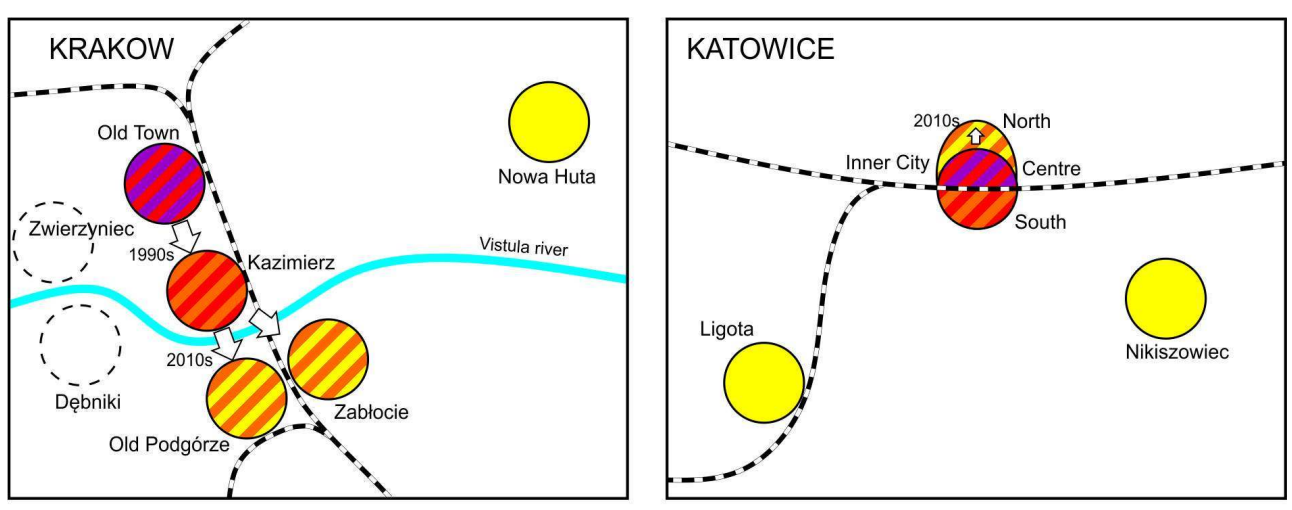

Perception of stages of development of artistic quarters by art students:
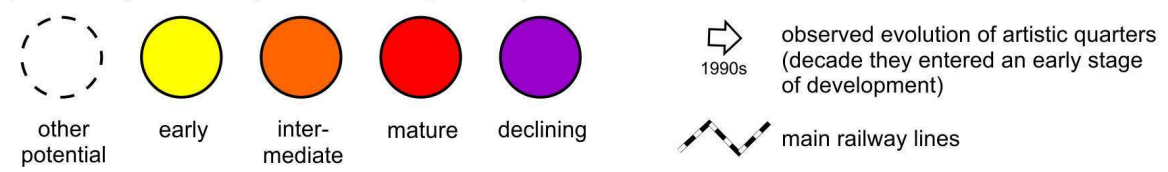

Source: own elaboration

Some artistic students still find inspiration in the old Town, despite growing criticism of the changes taking place in the city core. At the same time, however, this quarter is rarely regarded as a space for alternative art, and even if it is, this is thanks to just a few individual sites that defend its niche status in mainstream surroundings. Even fewer respondents see any possibilities or potential for rediscovering hidden features or spaces there. It thus follows that the old Town may be described as an artistic quarter at the stage of late maturity, approaching decline (in terms of its artistic life) (Fig. 2). This decline is, of course, relative rather than absolute, given the fact that so many major cultural institutions are located in the quarter, which will certainly continue to function as a place of cultural consumption, i.e. an art quarter. An independent art scene in the old Town, if one still exists, functions on the edge of the city core (e.g. Szczepański Square) and is not as visible as mainstream cultural expressions (Nacher, 2013). Kazimierz, in turn, despite exhibiting some features of a mature artistic quarter and some signs of decline, still seems to have potential for further development, as in this area an independent art scene continues to coexist with mainstream and commercial endeavours. Moreover, its growing touristification and transformation into a commercial night-life area has to some extent slowed down or even been reversed following the 2008 financial crisis. Consequently, despite commercialisation, it can still be considered as an area between the intermediate and mature phases of development.

Which quarters in Krakow are likely to become new territories of artistic exploration in the face of the growing commercialization of the current major artistic areas and their increasing contestation by some aspirational creatives? Two areas perceived as separate quarters are slowly coming onto the scene: the former Austrian town of old Podgórze and the post-industrial Zabłocie (fig. 1-2a, fig. 2). So far young artists see the greatest potential in Old Podgórze, which faces Kazimierz across the river, and since 2010 has been linked with it by a new pedestrian and cycle bridge. This potential artistic quarter seems to have all the features of an area attractive to artists: it is located in the immediate proximity of the city core and an established artistic quarter, has interesting architecture of diverse styles and scales, and a history of being perceived as a less prestigious, 
working-class neighbourhood. Neighbouring Zabłocie is completely different. It is a postindustrial quarter, which until recently had very few residents. Its built tissue is of lower architectural and artistic quality and comprises mainly factory buildings, warehouses and office buildings, which are not as interesting as the post-industrial architecture in other Polish cities such as Katowice. Still, the typical, large but modest scale of the postindustrial buildings within the quarter, termed by Green (1999) "large domestic", are an advantage of this type of built tissue which makes it easier to adapt to the needs of artists than some sites of former large industrial plants such as steelworks or mines in Upper Silesia.

Both quarters are visibly present in students' minds as spaces of avant-garde activities, inspirations or potential art presentations. For some (still relatively small) percentage of respondents the two areas are already sufficiently acknowledged as centres of artistic life so they also go there to search for professional contacts. This spread of answers places both areas between the early and intermediate stages of development, when a quarter is gradually gaining in popularity among artists, not only those representing alternative scenes.

There are, however, also visible differences in perceptions of the two parts of the city. Old Podgórze is regarded by aspirational creatives as a new territory still largely devoid of particularly striking or important artistic sites (apart from the KSA art school). For now it thus seems to be a largely imagined artistic quarter rather than a real one, its image largely influenced by media narrations hailing it "the next Kazimierz". Despite this discourse, there are no specific initiatives which have had a strong impact on young artists' mental maps of the quarter. ${ }^{5}$ Such strong "focal points" are visible in the artistic landscape of Zabłocie - in addition to the major public investment that is MOCAK, there are also other, smaller, private initiatives making use of post-industrial spaces, such as Wytwórnia (an art and design cooperative) and Bal (an artistic café and lunch bar), both located in the complex of the former electronic components factory where the faculty of architecture and art of A.F. Modrzewski Krakow University is also based, and Fabryka (Factory) - a club and cultural centre occupying part of a former cosmetics factory complex.

29 The quarter of Nowa Huta is a slightly different case. Among the students it ranked second among areas still with undiscovered potential. It is also relatively often cited as a space with alternative activities or inspiring for creatives. Despite that, it still does not have a strong enough image as a centre of artistic life to be attractive to young artists as a place to present their work. This potential artistic quarter is thus at a very early stage of development.

Two further quarters in Krakow indicated as areas still with undiscovered potential are two historic zones facing each other on opposite banks of the Vistula river west of the city core: DĘbniki and Zwierzyniec (Fig. 2). Although mentioned by some respondents, on the whole they are still barely visible on the mental map of the city and do not show any very visible signs of artistic vitality. They do have features (proximity to the city centre, interesting architecture, riverside location) conducive to development as artistic quarters in the future, though their evolution in this direction faces many obstacles. In Zwierzyniec factors likely to limit such development are high real estate prices and the perception of some of its areas and streets as elite. In the case of Dębniki, real estate prices and its isolation from other historic quarters by a major transport throughway are significant disadvantages. 


\section{Katowice}

31 The perception of Katowice is quite different and less complex than that of Krakow (Fig. 2, tab. 4). In this city, rather than broader urban areas three specific institutions are pointed to as places bustling with artistic life, i.e. the Academy of Music and Academy of Fine Arts in the southern part of the inner city, and "Rondo Sztuki" ("Roundabout of Art") gallery in its northern part. What was one of the city's main streets prior to the $19^{\text {th }}$ century, Mariacka Street, to the north of the main railway line (JarzĘbska et al., 2013), was the only other significant site of concentration of artistic activities mentioned by respondents. Despite a lack of (or very few) perceptions of the city in terms of specific artistic quarters occupying larger urban areas, the vast majority of artistic places and spots mentioned by students of artistic majors studying in Katowice are located in the area broadly regarded as the Inner City (fig. 1-1c), which overlaps with the highest density of firms in the creative industries sector (Drobniak, 2011).

In contrast to Krakow, public cultural institutions and artistic schools are most often cited as key to establishing professional contacts in Katowice. The Academy of Music complex was mentioned by one in three respondents from Katowice. Its success as an artistic venue and meeting place strongly visible on the mental map of the city seems to a large extent to be linked to its high architectural quality; the fusion of historic $19^{\text {th }}$ century buildings and a well-designed modern wing has created one of the most interesting public spaces in the city.

Mariacka Street is also an unquestioned epicentre of Katowice socialising, entertainment and nightlife economy. The street itself, as well as several named venues on it, were mentioned by half of respondents. The leisure sites named by young bohemians in Katowice are also nearly all concentrated in the city centre (A1 and A2), particularly in the oldest part of the city, north of the main railway line (fig. 1-1d). Among the establishments on Mariacka Street, two should be mentioned above all: Kato.bar and Katofonia, which combine the function of hangouts and bars with that of forums for visual arts, design and alternative music. The sole important point in the southern part of the Inner City (dating from the interwar period) is Hipnoza Jazz Club in the large building of the Municipal Cultural Centre. Among the few other places mentioned as once popular, Mariacka Street is also listed, as is the adjacent Stawowa Street, as well as particular clubs, cafes and cultural institutions in the city centre.

Thus in the case of Katowice the answers of young artists suggest existence of an artistic quarter in the inner city, although it is far more ambiguous and less evident in comparison to the clearer perceptions of artistic quarters in Krakow. We should also add that the intensity of artistic activities in the Inner City of Katowice is much lower than in the Old Town of Krakow, as it is spread out and dispersed over a larger area and divided into three subzones dissected by transport axes. In the context of Katowice, the central part of the Inner City, with an artistic and entertainment area focused mainly on Mariacka Street, may be located between the mature and declining stages of development, whereby the development of the night-time economy overshadows its artistic functions (Jarzębska et al., 2013). The southern part of the Inner City experiences less pressure of this kind. Perceptions of this area suggest an overlap of the intermediate and mature phases, though its artistic life is dependent on public institutions such as artistic schools and cultural institutions to an above average extent. The visible 
fascination of aspirational bohemians with currently implemented public cultural flagships in the northern part of the Inner City (A3) seems to be perpetuating this trend. Representations of this part of the inner city are thus very much influenced by public policies, which propel it faster toward an intermediate stage of development (Fig. 2).

Consequently, in Katowice, where a still underexplored artistic potential exists in the central part of the city, which, moreover, does not experience as strong overall real estate development pressure as the city centre of Krakow, it is rather unlikely that significant migrations of artists will occur from the city centre to newly discovered areas. If they do, this may come about faster in quarters or areas in closest proximity to the northern part of the city centre. The greatest still underexplored potential is perhaps dormant in two other quarters: Nikiszowiec and Ligota (fig. 1-1a), which are perceived as areas at an early stage of development. In both of them there are already interesting new avant-garde initiatives mentioned by students, such as Przestrzeń Twórcza Stacja Ligota ("Ligota Station Creative Space") at an abandoned railway station, and "Wilson Shaft" in the area of the former Wieczorek coal mine on the edge of Nikiszowiec. Some interest (although for now not particularly pronounced) is also visible in other individual post-industrial buildings such as Baildon Steelworks and Szopienice Steelworks, and in other parts of the city, such as Giszowiec and Załణ̨że, the area in which the 2014 Katowice Street Art Festival was based.

\section{Conclusions}

36 Analysis of the perceptions held by students of artistic majors with respect to artistic spaces in Krakow and Katowice reveals varying valuations of different parts of these cities, which may be to some extent interpreted from the point of view of the stages of artistic quarters' development present in the literature (tab. 1, fig. 2). In-depth analysis of the two cities, however, reveals the need to take account of several other important considerations and factors impacting on urban transformations and an area's progression from one development stage to the next, and of the limitations of such a theoretical framework. First of all, the transformations of urban spaces in terms of their functions and perceptions as artistic quarters are not as straightforward and linear as earlier studies might suggest. Secondly, such stages should be understood as "ideal types" rather than an exact reflection of any real state of affairs, as the same area might simultaneously exhibit co-existing features of two or even more stages of development as an artistic quarter. Consequently, categorization of an area into a particular stage hinges on dominant perceptions and features rather than the presence or absence of all of a list of symptoms. Artists' spatial perceptions and preferences are important, but are only one of many factors influencing urban transformations related to art and culture; other, nonartistic local and non-local factors can be of great significance as well, especially in the current post-crisis and increasingly neoliberal context. Creatives have to adapt to existing built tissue and local context, which are linked to the historical experiences and development path of a given urban centre, and this is clearly visible in the case of Poland. Last but not least, artists, including young artists, are themselves a very diverse social and professional group prone to significant internal differentiations. The paragraphs below briefly discuss the above limitations and considerations.

Gathered together, the answers given by individual young artists offer a broader view of how particular areas in the two cities are perceived. Perceptions of a specific area 
sometimes overlap, however and seem contradictory. The same quarter viewed by certain students as a setting for avant-garde activities, is by others regarded as a mature artistic quarter, or even an area dominated by commercial catering establishments (tab. 4, fig. 2). In some cases, despite the dominant perception of an area as mainstream or even declining, some respondents are still able to find avant-garde niches in it. Others list established cultural institutions which might be regarded as mainstream but are located in areas with still underexplored artistic potential (e.g. MOCAK in Zabłocie). Though the stages of development of artistic quarters as described in the literature are fairly clearcut and easily distinguishable, their actual evolution is thus much more complex and ambiguous, evincing combinations and variations of different stages.

The size of the city and its population, the level of development of its cultural and artistic life (visible, among other indicators, in its population of students of artistic majors), and its urban structure and functions all affect the dynamics of the development of artistic quarters in these two urban centres. In Krakow the artistic world is large enough and the pressure of other actors (developers and other commercial actors, tourists and students of non-creative majors) strong enough to initiate noticeable, recently observed flows of artists within the city. The evolution of artistic quarters is also visible taking into account the fact that the members of the aspirational creative class perceive artistic spaces in Krakow from the point of view of several distinct, larger areas or quarters which either already fulfil the function of artistic (and entertainment) quarters or are perceived as potential creative areas. In Katowice, on the other hand, a city with a large downtown but without a clearly perceived city centre (Murzyn-Kupisz, Gwosdz, 2011; Bierwiaczonek et al., 2012), and with a much smaller population of artistic students, we may for now speak of an artistic quarter in the rather ambiguously defined central part of the city where cultural life is vibrant in isolated, scattered "pockets" or specific institutions rather than across broader areas (Fig. 2). In addition, for now there is less likely to be a flow of artists in Katowice out of the city centre to other areas, not only because there are still numerous sites and buildings available for exploration in the inner city, but also because there is no significant pressure from other actors pushing them out to more peripheral districts.

39 The concentric urban structure that developed in Krakow prior to World War II is conducive to the spreading of cultural life from the city core outwards, to adjacent areas around the medieval old Town. These quarters or areas are, moreover, easier to distinguish from each other, as each has their own landmarks, to some extent unique urban tissue, and their own history of development, some of them as former satellite towns or villages around the historic metropolis. The former "ideal socialist city" of Nowa Huta marks the departure from this rule, as it was built at a considerable distance from the historic city core, east of the city centre, diverging from the concentric development pattern of Krakow and creating an east-west axis. This feature (distance from the city centre) might make the development of this area as an artistic quarter more difficult and less likely despite its unquestionable potential and the growing interest in post-socialist heritage. On the other hand, its architectural and spatial uniqueness continues the tradition of easily distinguishable urban areas in Krakow, and this could be conducive to its recognition as a unique artistic quarter. In many respects, then, Krakow reflects the evolving geography of artistic quarters observed in Western Europe, though its progression was delayed by Communism and then accelerated by the dynamic changes and pressure from commercial actors after 1989. From another perspective, the certain 
hesitance visible among young artists and "lack of eagerness" to explore new areas may stem not only from their insufficient knowledge of the city or lack of experience but also from the fact that there are relatively few particularly interesting and unique historic pre-war quarters in Krakow still left for artists to begin to explore. Most of the culturally interesting historic areas have already been "discovered" in recent years and explored, not so much by artists as by stronger commercial actors, which will make it all the more difficult for artists to find such places in the future.

In Katowice each successive period of history brought the wish to break with the idea of the city centre inherited from the previous one (Murzyn-Kupisz, Gwosdz, 2011). At the same time, particularly after World War II, several once autonomous villages and small industrial settlements were randomly attached to the city as it grew. Due to pressure from both German and Polish pre- and post-war authorities to project their vision of the city and for a new city core, these developments resulted in a large downtown area but no one easily distinguishable city core, despite the unique features of its different parts (e.g. the "German downtown" north of the railway line, the "Polish, interwar downtown" south of it, the socialist-modernist city centre north of the $19^{\text {th }}$ century German city). As mentioned earlier, none of the historic areas described above seem to be perceived as separate artistic quarters. They are seen more as one larger central area with three subzones representing different stages of artistic development. On the other hand, potential creative areas that are easier to distinguish and delimit - former industrial settlements or workers' quarters with clear boundaries, such as Nikiszowiec - are located at some distance from the city centre and are separated from it (also in popular perception as separate "islands", often "islands of poverty and decay") by large railway complexes, industrial or post-industrial areas, and socialist-era housing estates, making the "flow" of artists to them much more difficult. In this case a factor conducive to the spread of artistic impulses from the central area of the city to other quarters could be the development and improvement of public transport, as well as the existence of many still underused and unexplored post-industrial areas. This is nevertheless contingent on Katowice's reaching a critical mass of artists willing to venture into new spaces. In addition while in Krakow the river, largely neglected to date, could in the future become an important spine connecting old and newer artistic areas, in Katowice both the main railway line and major transport arteries constitute significant barriers to the development of artistic quarters (fig. 2). For now, the flow of artists from the city centre to other areas in Katowice is less likely not only due to the city's relatively fragmented structure, however, but also because there are still numerous sites and buildings to explore in the inner city. The weaker pressure on some parts of the city centre is also linked with the fact that in contrast to Krakow, which is number one tourist destination in Poland (for example in 2013 the city recorded over 1.626 million overnight hotel stays), Katowice is not a tourist city at all (in 2013 only 242,000 overnight hotel stays were recorded in Katowice, most of them pertained to business tourists) and the city also has a much smaller student population. There are thus visibly fewer potential clients for many artistic establishments and fewer actors exerting non-artistic pressure on creatives to move out of the city centre to more peripheral districts.

41 A further in-depth analysis of the answers of aspirational artists produces a still more nuanced picture of the functioning of artistic quarters. The historic artistic quarter that overlaps with the historic city core that is Krakow's Old Town is suffering from the strongest commercialization, touristification and commercially oriented gentrification. 
As a result, it is evolving into an artistic and entertainment-related consumption quarter offering mainly mainstream and high-end culture in major public (highly institutionalized) cultural institutions to tourists, students and middle-class residents. More avant-garde, independent cultural initiatives are pushed away from it, displaced to its fringes or other quarters. In Kazimierz, in turn, which developed spontaneously as an artistic quarter in the 1990s (Murzyn, 2006), independent artistic endeavours are still more vibrant but are also showing a tendency to gravitate more and more towards the main stream or at best semi-main stream, which is reflected in the developing discourse on the "loss of authenticity" and "creative vitality" of the quarter (Murzyn-Kupisz, 2012). The development of the latter mentioned artistic quarter came before the era of fascination with the policy of creative cities and possibilities of financing of flagship cultural investments with the help of EU funds.

These two factors may and in fact do have a significant impact on the development of the area on the south bank of the Vistula river, south of Kazimierz, i.e. Old Podgórze and Zabłocie, where some major public cultural investments have come online in recent years (two major museums in Zabłocie, and the Tadeusz Kantor centre in Old Podgórze) or are to be completed in the near future (plans to convert the former Salt Store into a Literature Centre). The media discourse which accompanies such developments, referring to new, trendy spaces, undoubtedly has an impact on some bourgeois bohemians and middle-class residents and investors in the city who want to follow changing fashions and are likely to decide to live in the usually newly built apartment buildings offered by developers who are more than happy to benefit from the promotion of such quarters as artistic and stress this new image of them, reinforcing it to their own advantage. Many such companies, often with foreign capital, bring the experiences of Western European and American investors to Poland. In the case of Katowice the development of an artistic quarter in the broadly understood city centre and on its northern edge is also to a large extent linked to action taken by public authorities in a continuation of the ideas and projects initiated during the bid for the title of European Cultural Capital 2016 (Tölle, 2013). The spatial preferences of young artists and the directions of development of artistic quarters are thus the outcome of two parallel forces. On the one hand individual artists or small, unorganized groups of them make spontaneous location decisions initiating and sustaining processes of urban change. On the other, their spatial preferences and wherewithal to follow them are to a large extent influenced (inspired or constrained) by the activities and actions taken by other, often financially stronger actors such as real estate developers (larger housing and office projects), public authorities (major investments) and the tourism sector (tourism accommodation and services).

Another important insight which emerged from the analysis is the need to disaggregate (young) artists, and to recognize that their experiences of urban space might vary and that different perceptions of the same quarters, preferences for acknowledged, "established" art quarters, and willingness to explore emerging or potential artistic quarters might to some extent be linked with their professional and socio-demographic characteristics, such as gender, number of years spent in a particular city, or the artistic genre they represent. Such in-depth analysis was possible in the case of Krakow, where a larger number of respondents took part in the survey. Analysis of students' answers suggests that the probability of more interest in avant-garde areas and the search for new places to conduct artistic activities in the urban space are not linked in any way with the features of the areas where young artists live or correlated with an artistic family 
background. The gender of respondents matters to a greater extent; males are more likely to be artistic pioneers than females. Similarly, length of time spent in Krakow seems to be important, as people who had recently moved to Krakow (up to 2 years before the survey) were much more likely to prefer traditional, established artistic quarters and were less likely to be explorers into new areas, probably due to their limited familiarity with the city and focus on the best known historic quarters, which is typical for newcomers to Krakow. The factor that goes furthest towards explaining variations in urban perceptions of young artists, however, is the type of artistic genre they practise and the type of artistic school linked with it. Students of the Academy of Music are the artistic group that concentrates most in mature artistic quarters, particularly the old Town. Similar predilections for more mainstream artistic quarters are visible among future actors and theatre directors - students of the State Drama School - and to some extent students majoring in fashion design, although among these there is also a small group more interested in emerging artistic quarters. One of the main reasons for such "conservative" preferences is the specificity of these three artistic genres. For musicians and representatives of the dramatic arts, access to prestigious public cultural institutions and artistic gatekeepers located mainly in the old Town art quarter is of key importance for practising and displaying their artistic skills. Young fashion designers are probably motivated above all by access to the broader pool of potential clients in central areas popular among tourists and non-artistic residents. Visual arts and architecture students in turn are most likely to be interested in exploring new areas of the city. Visual artists often search for new inspiring sites, social milieus and landscapes in defiance of classic academic trends. As in their case the process of artistic creation and the moment of presentation of its outcomes do not overlap, they do not need to create in areas frequented by masses, and thus seek affordable studio space. Architects may be attracted to such new areas by the possibilities for designing new buildings in urban spaces undergoing rapid transformation with much room for architectural creation (e.g. postindustrial areas). Our research results indeed confirm that such students represent the largest group of pioneers and it is they (visual artists and architects) who could - in the context of both cities - do most to initiate transformations in some areas and quarters, with representatives of other artistic genres acting as their followers. Further interesting information offering possible explanations for the differing perceptions of the two cities, linked with their historic development paths, are not only spatial preferences within the city but also the reasons why artistic students chose to study in a particular city: whether positive valuation of its urban space played an important role or whether other considerations, such as the prestige of a particular art school or proximity of family, dominated. In fact, the former of these factors is very important for selecting Krakow as a city in which to follow an art major, while the second and third are more popular in the case of Katowice (Działek, Murzyn-Kupisz, 2014).

Although we must be circumspect in making forecasts about the future landscapes of artistic quarters in either city, even in the short term, the spatial preferences and perceptions of artists certainly offer some interesting insights into the tendencies and reasons behind urban transformations linked with the artistic quarter label. In Krakow it seems that the process will be faster and more widespread than in Katowice. The areas of Old Podgórze and Zabłocie, thanks to the proximity of two older, well-established artistic quarters and increasing penetration by tourists, seem to have greatest chances of evolving into more mature artistic quarters, although they also might (as some artists are already predicting) move into a decline phase without ever reaching maturity. It is much 
harder to predict where the hotbeds of avant-garde artistic activity will migrate after these two areas reach maturity. In the case of Katowice it is most probable that the inner city and its northern edges will long remain the centres of artistic life. Major development of more peripheral areas is rather unlikely unless significant changes occur in the broader urban context (e.g. selection of a particular area as a focus for urban regeneration policy, new flagship investments). Nevertheless, further careful observation of the processes of change will surely be an interesting direction of research, requiring the gathering of more diverse data both quantitative and qualitative to help construct a more complex and comprehensive perspective on the way such areas function. It would also help to improve understanding of the mechanisms of their transformation, especially the motivations of the different generations and categories of artists who stand behind the artistic evolution of particular parts of cities.

\section{BIBLIOGRAPHY}

AMBROSINO C. (2013), "Portrait de l'artiste en créateur de ville. L'exemple du quartier artistique de South Shoreditch à Londres", Territoire en mouvement, 17-18, Artistes et territoires créatifs en Europe (volume 1), pp. 20-37.

BAIN A.L. (2003), "Constructing contemporary artistic identities in Toronto neighbourhoods", The Canadian Geographer, 47, 3, pp. 303-317.

BALLESTER P. (2013), "Quartier d'artistes versus cluster numérique. Entre conflit foncier et production d'un nouvel espace créatif : le 22@ de Poblenou à Barcelone", Territoire en mouvement, 17-18, Artistes et territoires créatifs en Europe (volume 1), pp. 73-90.

BENNETT D. (2010), "State of play: live original music venues in Western Australia", Perfect Beat, 11, 1, pp. 49-66.

BIERWIACZONEK K., LEWICKA B. and NAWROCKI T. (2012), Rynki, malle i cmentarze. Przestrzeń publiczna miast ślĄskich $w$ ujĘciu socjologicznym, Kraków, Nomos.

BLESSI G.T., SACCO P.L., and PILATI T. (2011), “Independent artist-run centres: an empirical analysis of the Montreal non-profit visual arts field", Cultural Trends, 20, 2, pp. 141-166.

BOICHOT C. (2013), "Les espaces de la création artistique à Paris et Berlin : entre pôle artistique et centralité urbaine”, Territoire en mouvement, 19-20, Artistes et territoires créatifs en Europe (volume 2), pp. 19-39.

BRENNAN-HORLEY C. (2010), "Multiple Work Sites and City-wide Networks: a topological approach to understanding creative work", Australian Geographer, 41, 1, pp. 39-56.

BRENNAN-HORLEY C. and GIBSON C. (2009), "Where is creativity in the city? Integrating qualitative and GIS methods", Environment and Planning A, 41, pp. 2595-2614.

BROOKS D. (2000), Bobos in paradise: the new upper class and how they got there, New York, Simon \& Schuster. 
CAMERON S. and COAFFEE J. (2005), “Art, Gentrification and Regeneration. From Artist as Pioneer to Public Arts", European Journal of Housing Policy, 5, 1, pp. 39-58.

CATUNGAL J.P., LESLIE D. and HII Y. (2009), "Geographies of Displacement in the Creative City: The Case of Liberty Village, Toronto”, Urban Studies, 46, 5-6, pp. 1095-1114.

CHABROL M. (2011), De nouvelles formes de gentrification? Dynamiques résidentielles et commerciales dans le quartier de Château-Rouge (Paris), thèse de doctorat en géographie, Université de Poitiers.

CLERVAL A. (2008), La gentrification à Paris intra-muros : dynamiques spatiales, rapports sociaux et politiques publiques, thèse de doctorat en géographie, Université de Paris 1.

COLE D.B. (1987), “Artists and Urban Redevelopment”, Geographical Review, 77, 4, pp. 391-407.

COLLET A. (2008), "Les « gentrifieurs » du Bas Montreuil : vie résidentielle et vie professionnelle", Espaces et sociétés, 132-133, pp. 125-141.

COMUNIAN R., FAGGIAN A. and LI Q.C. (2010), "Unrewarded careers in the creative class: The strange case of bohemian graduates", Papers in Regional Science, 89, 2, pp. 389-410.

CURRID E. (2007), "How Art and Culture Happen in New York. Implications for Urban Economic Development", Journal of the American Planning Association, 73, 4, pp. 454-467.

DEBROUX T. (2013a), "Inside and outside the city. An outline of the geography of visual artists in Brussels (19th-21st centuries), Brussels Studies, 69, www.brusselsstudies.be [accessed February 17, 2014].

DEBROUX T. (2013b), "Les territoires créatifs : quelques notions théoriques et une analyse bruxelloise", Territoire en mouvement, 19-20, Artistes et territoires créatifs en Europe (volume 2), pp. 40-59.

DRAKE G. (2003), “'This place gives me space': place and creativity in the creative industries”, Geoforum, 34, pp. 511-524.

DROBNIAK A. (2011), “Katowice miastem kultury wysokiej i przemysłu muzycznego”, in KLASIK A. (Ed.), Kreatywne Przemysły - Kreatywne Aglomeracje, Warszawa, KPZK PAN, pp. 19-41.

DZIAŁEK J. and MURZYN-KUPISZ M. (2014), "Is Krakow attractive to young members of the creative class? Urban policy implications", in WIKTOR-MACH D., RADWAŃSKI P. (eds.), The idea of creative city. The urban policy debate, Kocani, European Scientific Institute, pp. 69-83.

EVANS G. (2009), “Creative Cities, Creative Spaces and Urban Policy”, Urban Studies, 46, 5-6 pp. $1003-1040$

GORNOSTAEVA G. and CAMPBELL N. (2012), "The creative underclass in the production of place: example of Camden Town in London", Journal of Urban Affairs, 34, 2, pp. 169-188.

GRAVEREAU S. (2013), "Les artistes de Belleville : valeur et faire-valoir d'un quartier de Paris à leurs dépens? ", Territoire en mouvement, 17-18, Artistes et territoires créatifs en Europe (volume 1), pp. 38-51.

GREEN N. (1999), “Artists in the East End 1968-1980”, Rising East, 3, 2, pp. 20-37.

GWOSDZ K. (2014), PomiĘdzy starĄ a nowA ścieżkĄ rozwojowĄ. Mechanizmy ewolucji struktury gospodarczej i przestrzennej regionu tradycyjnego przemysłu na przykładzie konurbacji katowickiej po 1989 roku, Kraków, Instytut Geografii i Gospodarki Przestrzennej.

HAMILTON F.E.I. et al. (2005), Transformation of Cities in Central and Eastern Europe: Towards Globalization, New York, United Nations University Press. 
HARRIS A. (2011), “Art and gentrification: pursuing the urban pastoral in Hoxton, London”, Transactions of the Institute of British Geographers, 37, pp. 226-241.

HEEBELS B. and van AALST I. (2010), "Creative clusters in Berlin: entrepreneurship and the quality of place in Prenzlauer Berg and Kreuzberg", Geografiska Annaler: Series B, Human Geography, 92, 4, pp. 347-363.

HRACS B.J. (2009), “Beyond Bohemia: Geographies of everyday creativity for musicians in Toronto" in EDENSOR T., LESLIE D., MILLINGTON S., RANTISI N. (eds.), Spaces of Vernacular Creativity: Rethinking the Cultural Economy, London, Routledge, pp. 75-88.

JAKOB D. (2012), “The eventification of place: Urban development and experience consumption in Berlin and New York City", European Urban and Regional Studies, 20, 4, pp. 447-459.

JARZĘBSKA A., JELEŃSKI T., WOŹNIAK-SZPAKIEWICZ E. (2013), Porozmawiajmy o Mariackiej, Katowice-Kraków, Fundacja MILA.

JUSKOWIAK P. (2012), “Gentrification, Art and Creative Sabotage in Poznan and Warsaw”, in KOOS L.R. (ed.), Hidden Cities. Understanding Urban Popcultures, Whitney, Disciplinary Press.

LANGE B. (2011), "Professionalization in space: Social-spatial strategies of culturepreneurs in Berlin”, Entrepreneurship \& Regional Development, 23, 3-4, pp. 259-279.

LAVANGA M. (2013), “Artists in urban regeneration processes : use and abuse?”, Territoire en mouvement, 17-18, Artistes et territoires créatifs en Europe (volume 1), pp. 6-19.

LAWTON P., MURPHY E. and REDMOND D. (2012), "Residential preferences of the "creative class'?", Cities, 31, pp. 47-56.

LEY D. (2003), “Artists, Aestheticisation and the Field of Gentrification”, Urban Studies, 40, 12, pp. 2527-2544.

LLOYD R. (2004), “The Neighborhood in Cultural Production: Material and Symbolic Resources in the New Bohemia", City \& Community, 3, 4, pp. 343-372.

MATHEWS V. (2008), “Artcetera: Narrativising Gentrification in Yorkville, Toronto”, Urban Studies , 45, 13, pp. 2849-2876.

MCAULIFFE C. (2012), "Graffiti or street art? Negotiating the moral geographies of the creative city", Journal of Urban Affairs, 34, 2, pp. 189-206.

MCCARTHY J. (2006), "Regeneration of Cultural Quarters: Public Art for Place Image or Place Identity?", Journal of Urban Design, 11, 2, pp. 243-262.

MOLOTCH H. and TRESKON M. (2009), "Changing Art: SoHo, Chelsea and the Dynamic Geography of Galleries in New York City”, International Journal of Urban and Regional Research, 33, 2, pp. 517-541.

MONTGOMERY J. (2003), “Cultural Quarters as Mechanisms for Urban Regeneration. Part 1: Conceptualising Cultural Quarters”, Planning, Practice \& Research, 18, 4, pp. 293-306.

MURZYN M. (2006), Kazimierz. The Central European experience of urban regeneration, Krakow, International Cultural Centre.

MURZYN-KUPISZ M. (2012), “Cultural Quarters as a Means of Enhancing the Creative Capacity of Polish Cities? Some Evidence from Cracow”, Quaestiones Geographicae, 31, 4, pp. 63-76.

MURZYN-KUPISZ M. and GWOSDZ K. (2011), “The changing identity of the Central European city: the case of Katowice", Journal of Historical Geography, 37, pp. 113-126. 
NACHER A. (ed.) (2013), Spacerowicze, nomadzi i sieciowi łowcy okazji, Kraków, Małopolski Instytut Kultury.

NOONAN D.S. (2013), “How US cultural districts reshape neighbourhoods”, Cultural Trends, 22, 3-4, pp. 203-212.

OCEJO R.E. (2011), “The Early Gentrifier: Weaving a Nostalgia Narrative on the Lower East Side”, City \& Community, 10, 3, pp. 285-310.

OLSZEWSKA M. (2012), Alternative nightlife in Praga Pótnoc. Alternative nightlife zone in a postmanufacturing district of Warsaw in the experiences of nightlife entrepreneurs, Master Thesis in Urban Geography, Utrecht University.

PURCHLA J. (2000), Cracow in the European Core, Krakow, International Cultural Centre.

RICHARDS P., KOMOROWSKA M., LATUCH M., ŁOWICKA K., MAMIŃSKA A., PLUTA K. and ŻUREK A.M (2010), City of Warsaw Supporting the Creative Industries in Praga Pótnoc. Guidelines for Development of an Action Plan, Warsaw, Creative Metropoles.

RYBERG S., SALLING M. and SOLTIS G. (2013), "Putting artists on the map: the geography of artists in Cuyahoga County, Ohio", Journal of Urban Affairs, 35, 2, pp. 219-245.

SAGAN I. and GRABKOWSKA M. (2012), “Urban Regeneration in Gdańsk, Poland: Local Regimes and Tensions Between Top-Down Strategies and Endogenous Renewal", European Planning Studies, 20, 7, pp. 1135-1154.

SAGAN I. and SZMYTKOWSKA M. (2012), Miasto $w$ dobie neoliberalnego urbanizmu, Gdansk, Wydawnictwo Uniwersytetu Gdańskiego.

SHARON B. (1979), “Artist-run galleries. A contemporary institutional change in the visual arts”, Qualitative Sociology, 2, 1, pp. 3-28.

SLACH O., BORUTA T., BEDNAR P. and KOUTSKÝ J. (2013), "Stodolní ulice à Ostrava : un exemple de régénération du centre d'une ville post-socialiste en République tchèque. Naissance d'un quartier culturel ou d'un espace de consommation ?", Territoire en mouvement, 17-18, Artistes et territoires créatifs en Europe (volume 1), pp. 52-72.

SMIT A.J. (2011), “The Influence of District Visual Quality on Location Decisions of Creative Entrepreneurs", Journal of the American Planning Association, 77, 2, pp. 167-184.

SWARTZ J. (2010), "Space-Run Artists: Cultural Activism in Contemporary Barcelona”, Leonardo, 43, 1, pp. 6-7.

SÝKORA L. and BOUZAROVSKI S. (2012), "Multiple Transformations: Conceptualising the Postcommunist Urban Transition”, Urban Studies, 49, 1, pp. 43-60.

TÖLLE A. (2013), “Transnationalisation of development strategies in East Central European cities: A survey of the shortlisted Polish European Capital of Culture candidate cities", European Urban and Regional Studies, doi: 10.1177/0969776413512845.

TRAVERSIER M. (2009), “Le quartier artistique, un objet pour l'histoire urbaine”, Histoire urbaine, 3, 26, pp. 5-20.

TREMBLAY D.-G. and BATTAGLIA A. (2012), “El Raval and Mile End: A Comparative Study of Two Cultural Quarters between Urban Regeneration and Creative Clusters", Journal of Geography and Geology, 4, 1, pp. 56-74.

VIVANT E. (2009), "How underground culture is changing Paris", Urban Research \& Practice, 2, 1, pp. 36-52. 
VIVANT E. (2010), “The (re)Making of Paris as a Bohemian Place?”, Progress in Planning, 74, pp. 107-152.

WEDD K., PETTZ L. and ROSS C. (2001), Creative quarters: the art world in London from 1700 to 2000, London, Museum of London.

WHILE A. (2003), "Locating art worlds: London and the making of Young British art", Area, 35, 3, pp. 251-263.

WOLDOFF R.A., DECOLA T. and LITCHFIELD R.C. (2011), "The aspirational creative class: Urban residential preferences of college students in creative majors", City, Culture and Society, 2, pp. 75-83.

ZEBRACKI M. and SMULDERS L., (2012), “Artists-accompanied urban regeneration: insights and lessons from Utrecht and Rotterdam”, Tijdschrift voor Economische en Sociale Geografie, 103, 5, pp. 615-623.

ZUKIN S. (1989), Loft living: culture and capital in urban change, Baltimore, MD, Johns Hopkins University Press.

ZUKIN S. (2008), "Consuming authenticity. From outposts of difference to means of exclusion”, Cultural Studies, 22, 5, pp. 724-748.

ZUKIN S. and BRASLOW L. (2011), "The life cycle of New York's creative districts: Reflections on the unanticipated consequences of unplanned cultural zones", City, Culture and Society, 2, pp.

131-140.

\section{NOTES}

1. The roles of artists in gentrification are highly varied. They may be 'pawns' of gentrification: inspirers and pioneers of the process; act as classic gentrifiers and displacers; or become displaced victims of gentrification forced to relocate to other areas.

2. Excluding Poland's capital, Warsaw, which due to its economic, demographic and cultural status cannot be compared to any other city in the country.

3. These included the Academies of Fine Arts and Academies of Music in both cities, the State Drama School in Krakow, the Faculty of Architecture at the Krakow University of Technology, the Faculty of Art at the Pedagogical University in Krakow, the Krakow School of Art and Fashion Design, two art-related faculties at the A.F. Modrzewski Krakow University, the Faculty of Radio and TV at the Silesian University in Katowice, and art-related majors at the Higher Technical School in Katowice.

4. 18 administrative quarters and 141 urban units in Krakow and 24 urban units and 53 urban subunits in Katowice.

5. In 2014 a new Tadeusz Kantor museum and interpretation centre opened in the area, which might contribute to future changes in its perception. 


\section{ABSTRACTS}

The phenomenon of artistic quarters has been explored by many researchers interested in the spatial behaviours of artists in North American and Western European cities. Their analyses have often focused on the impact of this occupational group on transformations of selected urban areas: the arrival of artists as pioneers in degraded, problem neighbourhoods and the evolution of those neighbourhoods, which then attract more established artists, followed by creative professionals and non-creative gentrifiers. As over time the built environment, functions, cultural, gastronomic offer and ambiance of such areas change significantly, their progressive mainstreaming and commercialization prompt some artists to venture into new districts and spaces. The article first offers a review of existing findings with respect to artistic quarters and their transformations. The discussion of the possible stages of development of artistic quarters present in literature is followed by the application of this theoretical framework in the context of Polish cities using the examples of Krakow and Katowice. These significant regional capitals represent two major types of urban centres in Poland: a city with medieval roots, and a city which emerged during the $19^{\text {th }}$-century industrialisation process. The phases of evolution of the artistic quarters in both cities are analysed by examining the spatial perceptions of students of artistic majors. The analysis shows that the transformations of urban spaces in terms of their functions and perceptions as artistic quarters are not as straightforward and linear as earlier studies might suggest. Krakow's more vibrant artistic life and its historic, concentric urban structure, combined with strong commercial pressures, are conducive to the development of new artistic quarters, although its traditional city centre continues to some extent to maintain its position on the artistic map of the city. In contrast, in Katowice the chaotic spatial structure of the heart of this historic industrial region makes the flow of artists more difficult and less likely, as they tend to concentrate in a poorly delineated area of the inner city. In addition, as the case studies reveal, spatial choices of artists are not only dependent on a city's development path and its built environment but are also to a significant extent shaped by the diverse artistic backgrounds of its creatives and a host of factors linked with post-socialist transformation and neoliberal urban policies.

Le phénomène des quartiers artistiques a été exploré par de nombreux chercheurs intéressés par les comportements spatiaux des artistes dans les villes nord-américaines et ouest-européennes. Leurs analyses se concentrent souvent sur l'impact de ce groupe professionnel sur les transformations des espaces urbains : arrivée des artistes pionniers dans des quartiers dégradés en difficulté attirant ensuite des artistes plus établis, suivis par des créatifs professionnels et des gentrifieurs non-créatifs. Avec le temps, l'environnement bâti, les fonctions, l'ambiance, l'offre culturelle et gastronomique du quartier évoluent de manière significative ; la standardisation culturelle et la commercialisation du quartier incitent alors certains artistes à s'aventurer dans de nouveaux quartiers. Notre article offre d'abord un aperçu des recherches existantes sur les quartiers artistiques et leurs transformations. La discussion des différentes étapes de développement des quartiers artistiques précède l'application de ce cadre théorique dans le contexte de deux villes polonaises : Cracovie et Katowice. Ces capitales régionales représentent deux types de grandes villes polonaises: la première ayant des racines médiévales, la deuxième ayant émergé au $19^{\mathrm{e}}$ siècle avec l'industrialisation. Les phases de développement des quartiers 
artistiques dans les deux villes sont analysées d'après les perceptions spatiales d'étudiants en art. Leur analyse montre que les transformations des espaces urbains, de leurs fonctions et de leur perception en tant que quartiers artistiques ne sont pas aussi simples et linéaires que ne le suggèrent les études antérieures. La vie artistique plus vibrante à Cracovie et sa structure urbaine historique, couplées à de fortes pressions commerciales, sont propices au développement de nouveaux quartiers artistiques (bien que son centre-ville traditionnel se maintienne sur la carte artistique de la ville). En revanche, à Katowice, la structure spatiale chaotique propre au cœur d'une région industrielle rend plus difficile et moins probable la circulation des artistes, qui ont tendance à se rassembler dans un espace assez vaste et mal délimité du centre-ville. En outre, comme l'étude le révèle, les choix spatiaux des artistes ne sont pas seulement dépendants des modes de développement d'une ville et de son environnement bâti, mais ils sont aussi largement façonnés par l'expérience personnelle des jeune créatifs et, dans les deux cas étudiés, par d'autres facteurs liés à la transition post-socialiste et aux politiques urbaines néolibérales.

\section{INDEX}

Mots-clés: quartiers artistiques, étudiants en art, créatifs, Cracovie, Katowice

Keywords: artistic quarters, art students, creatives, Krakow, Katowice

\section{AUTHORS}

\section{JAROSŁAW DZIAŁEK}

Institute of Geography and Spatial Management, Jagiellonian University, Krakow, jarek.dzialek@uj.edu.pl

\section{MONIKA MURZYN-KUPISZ}

UNESCO Chair for Heritage and Urban Studies, Krakow University of Economics, murzynm@uek.krakow.pl 